\title{
Hour Times mole Per Liter Per Milligram Per Gram Per Day
}

National Cancer Institute

\section{Source}

National Cancer Institute. Hour Times mole Per Liter Per Milligram Per Gram Per Day.

NCI Thesaurus. Code C117925.

Hour times mole per liter, divided by milligram per gram per day. 